\title{
The Folk High Schools, their Role and Activity today
}

\author{
By Thomas Rørdam
}

A couple of years ago a high-ranking Danish official visited the head of one of the largest industrial concerns in the United States. During their conversation they discussed Denmark's opportunities for an independent and economic role in the future.

The industrialist argued that increasing concentration of capital would result in less international freedom for the smaller Western countries. He felt that in the case of Denmark we should concentrate on fields of activity where we have already gained international recognition, such as, for instance, education.

That industrialist was no doubt right in saying that Denmark will have difficulty in having much say, politically and economically in the future world. As if she ever had! . . but now there are even less chances with multi-national concerns taking over - for better or worse.

The American did not specify what aspect of education he was thinking of. But judging by the experience of Det danske Selskab with foreign visitors year after year, the Danish Folk High School is one of the subjects in which they show most interest. Here you have an original Danish achievement in line with our public libraries, our cooperative dairies and parts of our social welfare system.

I found the same interest in the Danish folk high schools when in $1970 \mathrm{I}$ was invited to the United States as a guest teacher at the San Fernando Valley State College in California. The subject was Danish cultural and educational policies, but it was primarily the folk high schools they wanted to hear about - and, therefore, they had invited a Danish folk high school man.

During my stay in California I visited a non-examination 
boarding school for young Jews. It turned out to be a rather unique experiment, built on educational inspiration from Denmark.

The founder of the school and its present principal, Dr. Shlomo Bardin had emigrated from Germany to get away from the Hitler regime. During the 30s he stayed at Danish folk high schools Askov and Ryslinge - and what he saw and read about there, he tried to transplant to a kibbutz in California.

He said to me: "It was Grundtvig and Kold and the history of the Danish folk high schools that showed me how to awaken young Jewish Americans, how to make them feel as Jews".

Kristen Kold had in his thatched cottage-school at Ryslinge in 1851 aimed at Christian and Danish awakening. One hundred and twenty years later Dr. Bardin aimed at Jewish and American awakening. As Kristen Kold wished his pupils to become good Christians and good Danes, Dr. Bardin wished to make his students good Jews and good Americans.

I was able to participate in an ordinary day at the school. It began with the hoisting of the Flag while we sang the American National Anthem. Then followed instruction in country dancing and a period with Jewish folk songs, - community singing, as in the Danish folk high schools. - Then a drama lesson with scenes from the Song of Songs. Later a lecture on the history of the Jews just as Ernst Trier at Vallekilde folk high school a hundred years ago would have told it to his students. And running like a red thread through all the activities was obviously the wish that the young Jews should feel a real community spirit; should enjoy being Jews together.

It might be natural to ask, then, if the Danish folk high schools, as they are today, can live up to the expectations of this well-intentioned foreign educationalist. Well, this is rather doubtful. Great changes have taken place within the Danish community and likewise great changes have occurred in educational methods and in daily life at the folk high schools. The background is different now. Denmark is no longer a homogeneous agricultural community. Only 9 per cent of the population are occupied in farming.

But, then I suppose, it's just as doubtful whether one could call that Jewish school in California a folk high school. It only receives students from one small section of the population, a minority, and schools which only appeal to limited circles are not the folk 
high schools of Grundtvig - with stress on folk - just because they adopt a timetable similar to that of the folk high schools of many years ago. No, there is instead a real danger that they become simply centres with a narrow sectarian outlook.

What is exceptional about the folk high school - not least in the industrial society of today - is that it is a form of education where people with widely differing qualifications, from different environments and professions and also, maybe, of different ages, meet and take part in the same form of education - naturally without preparing for an examination or a diploma.

The folk high school establishes the basis of a small temporary community. But what is it that is to be held in common? This is a good question where togetherness is a key word in today's society. "Never alone" seems to be a motto for the individual's existence. This characteristic of togetherness, or community, at a folk high school is that people come together, not only for a casual side by side relationship, but also that they concentrate on a theme being taught at the school both in and after classes, otherwise the concept of folk high school would have no meaning.

A former principal at Rødding folk high school, Hans Lund, said that the folk high schools last century helped in making a peasantry into a people. This cannot be said about the folk high schools today. For there is no longer a peasantry. On the other hand we are more than ever, maybe, unaware of what happens outside our own line of work. This is the isolation which the folk high schools try to break today and this is why so many highly qualified people attend them. Because here they stay with people from completely different professions and backgrounds.

Today the students at the folk high schools have had a better education than before. Many of them, for example, speak foreign languages. Less than ten years ago the majority of students had left school at the age of 14 after seven years' schooling. Sometimes they had a further five months' stay at a continuation school, but that was all. Today almost all folk high school students have stayed at school until sixteen or seventeen, having done nine or ten years. With this recent explosion within education it is no longer necessary to devote so much time to elementary studies, which were previously an important part of a folk high school stay.

Another thing, of course, is that in spite of extended schooling 
and better education, the knowledge which the pupils get in the elementary school is in no way comparable with the knowledge they receive in other ways.

Last year the French minister of education said rightly that fifty years ago pupils received 75 per cent of their knowledge through the school, but today they get the same 75 per cent from outside sources like radio, television, picture magazines, youth clubs and so on. All this, understandably enough, has contributed to a change of the position of the folk high schools in the system of education. It has also changed the subjects of the curriculum. It has to be remembered that the folk high school ideas of Grundtvig constituted a framework. He did not elaborate the topics to be taught as did Kold and his disciples.

Methods of education also change constantly. There is now little difference between educational methods in the grammar school and the folk high school. Grundtvig calls the grammar school The black School. But the Black School is no longer black; it no longer gives one-sided instruction. Today the grammar schools also aim at promoting general cultural standards and the personal development of each student.

On the other hand, the folk high schools also include practical subjects in their curricula. They have to do this with a view to the student's continued training although all-round education is still dominant. But, unlike the grammar schools, they are open to all, irrespective of previous training and skills.

Another matter is that although there are no entrance limits, no entrance examinations or such, the folk high schools must, in practice, make up their minds whether they really wish to accept everybody who satisfies the age condition. Psychic rehabilitees, for example, are now often sent to the schools from rehabilitation centres, hospitals and welfare institutions. And many of these are or have been drug addicts.

I feel that the institutions which refer them are not always aware of their responsibilities and they know too little about the folk high schools. Most teachers have no psycho-clinical experience at all, so several folk high schools send a form to the applicants asking for age, educational background, professional training, former employment, the reason why they wish to attend and finally how a possible stay is going to be financed. And from the infor- 
mation received it should then be possible to judge if the applicant is suited to a boarding school environment.

A principal, a good friend of mine, always asks the institution in question, if they would recommend the applicant for a job. If this is not the case, he will not be accepted. After all - a folk high school is not a convalescent home.

But, apart from this qualification, there are no bars at all. The important thing for a folk high school teacher is not what the students know beforehand or whether they get through a prescribed syllabus. All important are - the students themselves - and they have also changed considerably in recent years.

Anyone who has taught at a folk high school for a number of years will be aware of the fact that young people from the modern industrial society have quite different norms and standards from earlier folk high school youth. They have another attitude towards money, alcohol, sex and the older generation, including the teacher.

As late as the end of the 1950s the majority of students still came from farming homes and among them quite a few from sects inspired by Grundtvig: They were the children and grandchildren of his religious and national revival and they knew beforehand about the folk high school movement.

Many of those who attend the folk high schools today have no idea of their traditions, they come from homes foreign to these schools. Many of the youngsters revolt against the traditional folk high school which they find authoritarian. They find the aims of the schools suspicious. They challenge bourgeois virtues by denouncing them. They do not sleep in beds but on mattresses on the floor. They consider any rules which they have not made themselves, offensive. To them even anarchy might be better.

This opposition to the old traditions is reflected in many ways. I can mention just a few examples: The older generation loved community singing and knew the Folk High School Songbook inside out. The young people of the 70 s have not inherited this love of community singing. Not those songs anyway. Many of the young students find the traditional songs, national and romantic as they are, far too heavy, incomprehensible, too unrealistic. These songs belong to a world of ideas which is totally strange. They belong to the past.

And like the songbook, the lecture itself is on the retreat. 
Many students find this form of education too passive and again - authoritarian. Previously the lecture was the centrepiece of the timetable. Other periods were just entr'actes. But today students prefer instruction in small groups where they can express their own opinions. And these opinions are, of course, not always the same as those of the teacher!

The folk high schools were once accused by their opponents as being hotbeds for personality cults. Maybe there was a grain of truth in it. This cannot be said today. The patriarchal school is certainly a thing of the past.

Reform and democracy is the order of the day. Student councils have been formed. Or school councils consisting of representatives of the students, teachers and the kitchen staff. In this way the students have a say in the running of the school - yes, even in the distribution of the educational funds - and in whom to invite as visiting lecturers.

Knud Hansen, former principal at Askov, wrote in the Folk High School Magazine in October 1969 something about democratization and the youth revolt. And some of his remarks are still valid.

He had this to say: "It is only a good thing if young people are awake and question what is really taking place at a folk high school and what use it is. It is also a good thing if they renounce authorities which are hollow and out of touch with reality. And it is splendid if they put a big question mark over the technological rat race in which so many people simply have no time to live.

But then he continues: "But one also gets the impression that a lot of time has been wasted at the folk high schools, just discussing nothing at all. One has debated education abstractly for the sake of a debate instead of bringing it to life in the classroom, and making one's own real contribution and, thereby, giving education a meaning. Democracy has been discussed so often that democratic feeling is running thin. You do not get nearer to democracy by discussing it, but by showing it within your own surroundings".

His criticism was an attempt to avoid flagrant abuse of student democracy, but also because he wanted to show that the rather hackneyed term "community spirit" often is misunderstood. It is true that community spirit is an important part of a folk high school experience, but if you do not find it in the actual activities 
of the school, - if you can only find togetherness when you are having an airy-fairy discussion about nothing at all, then you might just as well seek this togetherness - and possibly even more valuably, on a package tour to Mallorca.

Knud Hansen's criticism was primarily against the old folk high schools today. But new schools are still being opened which break with old traditions. I shall tell a little about them in a minute. Meantime a word about one folk high school plan which was not carried out. This was the suggestion for a State Folk High School, which another principal at Askov, Harald Engberg-Pedersen, put forward in 1970.

He said: "We have experienced a restriction of intellectual liberty and in this situation it might be an idea to realize $\mathrm{Kaj}$ Thaning's old suggestion of State folk high schools. Just as intellectual liberty thrives better in the State church than in free congregations, so liberty would be safer in a State high school which at the same time could sponsor valuable experiments within adult education. There would be no board members - they always fear experiments!"

Kaj Thaning, a well-known minister of the Danish Church and a Grundtvig scholar, who will be lecturing at this seminar took part in the discussion as a former folk high school teacher and founder of one of the newer Danish folk high schools.

Referring to these remarks, Mr. Thaning himself wrote a couple of days later to a Danish newspaper that to-day he would not dream of reintroducing his old suggestion of 1948. Times have changed considerably. In 1948 anyone opening a folk high school would have had to find one third of the initial expenses and that was almost impossible. Therefore, the private capital needed had to be reduced to a sixth with further cheap loans from the State.

In $1948 \mathrm{Mr}$. Thaning gave three reasons for establishing State folk high schools. Firstly, the name itself would appeal to the young people from the towns who did not wish to attend special workers' high schools, nor the traditional high schools for the farming population. Secondly, it might be possible for the State to save some of the small high schools in out-of-the-way areas even if the young people of such districts preferred to go to the larger and more centrally situated high schools. It was important to save the small schools - they had become cultural centres in their area. And 
by their existence alone they sent more people from their own district to other folk high schools then they had students themselves. The third reason was that the freedom of the folk high school could get a chance if the State secured the liberty of the principal for a period of five years. He quoted one of our great folk high school people, Holger Begtrup, (1859-1937) in saying: "It is not the State that threatens our liberty; it is our customers". Begtrup was of the opinion that in order to get as many students as possible - and, by that, as good an economy as possible - the folk high school principals dared not speak freely, but had to play up to prospective students. The State could give the school more freedom by making it economically secure.

Today, however, Mr. Thaning wrote - the situation of the folk high schools has changed and he could no longer support the idea of a State institution. It was simply not necessary any longer. With the new large State grants finance had improved immensely, also for the smaller schools. Nowadays speech was much freer because no one was afraid of telling unpleasant truths to prospective customers.

So while the suggestion of opening State schools never got further than deliberations, a few private schools have been opened in recent years which try to reflect the new ideas of today's society. With a few exceptions they are founded by organisations, while previously it was an individual or a group that took the initiative.

Two folk high schools have been opened by groups linked closely with traditional political work: The Trade Union Folk High School at Elsinore and "Brejdablik", a liberal folk high school at Holte.

The trade union folk high school is, as the name suggests, linked with the trade union work of the Danish Labour Party. It has no traditional education. The teacher has been replaced by groupwork and the curriculum does not include elementary subjects. The main items are the democratization of education, professions and places of work and leisure time problems.

The school has 149 single rooms for the students, each with toilet and bath. The students live in six blocks with 20-30 students in each. In 1970/71 it ran long courses of 13,17 and 30 weeks duration and in addition 67 courses lasting one or two weeks each.

In Svendborg "The Socialist Folk High School" will be laun- 
ching its first course on 1st October this year. It has been founded by the association "The Socialist Folk High Schools" which bought an old merchant's house and transformed it into a school. The curriculum includes working conditions and trade union matters and the school is in close contact with the factory floor and workshops. Like the Trade Union School the Socialist Folk School will have no traditional instruction. The prospectus talks about "breaking down the traditional barriers between teachers and pupils which a class-divided society has inflicted on us" and, instead, the school will be run as a collective.

A group of promoters has been formed and a school board and what otherwise is demanded by law, but the school collective will put it all out of action. The principal, in reality, is just there as their representative to the authorities.

Everyone at the school participates equally in all kinds of activities: washing floors, cleaning lavatories and cooking as well as sharing the theoretical and administrative work. Only in this way, it is maintained, can the class divisions, which exist in our capitalist society, be pulled down.

The prospectus continues: "Socialism is not only theory but a way of life which makes it impossible - as at the old folk high schools - to employ a proletariat of kitchen maids who did nothing but clean and cook for others".

In Kolding former teachers from Askov are building a folk high school which will have courses all year round. The individual student can take part in one month's, two months' or three months' work, according to his wishes. Kolding folk high school will not have classrooms, but there are a number of lounges, study rooms and workshops built in conjunction with the living quarters. There is no traditional timetable but a workplan for each month and for each year. The participants do not enrol "for a winter's stay at a folk high school" but for particular study groups and research projects. It is stressed that the school should be a working community dealing with vital social problems.

It is maintained that education should have a close contact with society. The participants will for example not only learn about the theory of local politics, but also attend the town council meetings, and thereafter, return to the folk high school to discuss the measures which should be taken in the given situation. It is 
further planned that the participants will make a study of the local unemployment problems.

Kolding Folk High School is to be a working collective. This will be strongly emphasized to eliminate the artificial barrier that is said to exist between teachers and students. The teacher cannot be a figure of authority that merely administers the laws and directs the students.

As at the Socialist High School, there will be no one to wait on the students. The first student groups will, in addition to other practical work, have to participate in the actual building of the school. The post as principal is only administrative and is taken in turn for one year at a time.

An equally untraditional folk high school experiment is the Travelling Folk High School on Fanø. This Folk High School has a number of class rooms on the ground floor of the former Beach Hotel. Above are bedrooms. The folk high school opened in 1970 and has three courses a year starting 1st March, 1st May and 1st September respectively. Approximately 40 students and 5 so-called veterans are enrolled for each course. The veterans are the persons who are formally engaged by the school as teachers and they between them choose new veterans from previous intakes. So the system is self-selective.

Each course lasts 9 months and is divided into three periods. The first period consists of two months' stay in Denmark, preparing for a journey by collecting information about the problems of the developing countries, the science of nutrition, the use of cameras and tape recorders, and last but not least languages and motoring. A knowledge of the bus-engine is necessary if the bus has to be repaired during the journey through remote and underdeveloped areas. The second period is a 4 months' trip by coach to Asia and finally during the third period of three months in Denmark the material gathered is worked up. At the same time Danish social questions are investigated.

The state only recognizes the part of the educational activity which takes place inside Denmark; the rest the student will have to pay for in full.

During the first period 5 groups are formed with 8-10 participants in each, the so-called bus-groups, with a veteran in each 
group. These groups work together during the bus trip to Asia. The participants are in turn drivers and the buses function as hotel, school and transport.

In the letter of introduction it is stated that "The Travelling Folk High School offers an intensive study of the developing countries". Its unexpressed aim is to fight imperialism, but in practice it will map out relations between the rich and the poor parts of the world. The idea is to show how the Western industrial countries have divided the world market among them, thereby exploiting the poorer countries.

There are particularly three factors which characterize the last three schools I have mentioned:

First that principal and teachers relatively speaking take a back seat.

Secondly that practical work is done even without domestic help and

Thirdly that the political element plays a greater part than in the folk high schools generally. He, however, who knows his Grundtvig, will also know that the folk high school at Soer mentioned by Roar Skovmand in his lecture, was intended to be political, so there is nothing shocking about that. It furthermore links up with the growing student interest in social subjects. All the same, the three schools mentioned have a rather narrow political outlook which may not be everybody's cup of tea.

Previously when students came from practical work in field or kitchen, it was unnecessary to stress the importance of cooperation in carrying out the concrete tasks of a folk high school. It is quite another thing today with so many students to whom a stay at a folk high school is just part of a constant training for 12 to 14 years.

There is no doubt that work methods which include practical work at a boarding school have added educational possibilities. But it presupposes undeniably that the work is done in such a way that the school is not buried in dust and dirt and one could really ask; Is it worth their while? I, for one, do not agree with the high school people who maintain that there is more "high school" in doing practical work together than in a study group on sociology or literature. A folk high school should not be confused with a 
work camp. On the other hand, however, it is a good thing if the students assist in carrying out certain tasks under the supervision of the kitchen staff.

One must not forget that the majority of students still come from practical work. If they have only 4 or 5 months in which to study, real folk high school work would suffer, if they had to do too much shopping, washing up, cleaning and repair work. The day when a sabbatical year becomes more common and when people of more mature age join a folk high school course, there should be more time for such work methods (Sabbatical year: a year free from work (with pay) that can be used for travel, vacation or further studies related to one's profession or special interests).

In spite of these new experiments the folk high school is still mainly an educational institution for adults. While preparing the new Act in 1970 it was realised that the suggestion of lowering the minimum age to under $17 \frac{1}{2}$ was impossible. Instead special youth folk high schools have been founded. There are four: Vester Vedsted, Egå, Andebølle and Oxbøl. These youth folk high schools are for 17-19 years olds and for 16 years olds who have just finished 10 years' schooling. Most of these students come directly from the elementary schools without having been out in practical life.

The students at these youth folk high schools are different from the students at ordinary folk high schools in other ways than age. Very often they are sick and tired of going to school and this makes the job more difficult for the teacher. And having just finished a decade of schooling they need no elementary subjects.

There is a great desire for experimenting among the teachers who themselves usually are young. "We have no traditions to hold us back", said one of them recently. Two of these schools, Andebølle and Oxbøl, are run collectively. The teachers are together responsible for the running of the school and for the administrative work which is usually done elsewhere by a principal.

The Youth Folk High Schools lie somewhere in between continuation schools and the real folk high schools. As I have already said they cater for 17 to 19 year olds while the other folk high schools have a large range of ages among the students. Yes, they also cater for people at the other end of the age scale. Recently folk high schools have been opened for old age pensioners and 
this together with special courses for elderly people was at the start something of a sensation.

Today pensioners' folk high schools are in full swing in Nørre Nissum and in Kolt near Aarhus. The Association of Clubs for Elderly People have far advanced plans for new pensioners' folk high schools, for example one to be opened in a former hotel in Sønderborg, South Jutland.

There are now folk high schools which have creches and kindergartens and at Herning a new family folk high school, Skærgården, will be opened in September, with rooms for 70 students. It has been founded on the initiative of the Danish YMCA. The school has four-month courses as well as shorter ones - and in this it tries to follow up the great success which the holiday courses for families turned out to be.

But why exactly family high schools? There are three reasons. One. Many breadwinners have not the necessary education to start the kind of work they would really like to do. Two. The problem of where to put the children when the parents attend a folk high school is being solved - and a free-school is included in the plans. A number of practical problems such as letting their flat during the course is arranged through the school; and Three. It appears that the individual families' isolation in a modern society where contact is lacking is a problem for parents as well as for the children.

Instruction is given in elementary subjects like Danish, arithmetic, and languages and it should cut through age divisions. There is still a great demand for this kind of elementary education as far too many parents have received an education which is insufficient to be accepted at Teachers' Training Colleges or other educational institutions. They must attend a course at a folk high school as part of changing their jobs. Mr. Knud Magnild and his wife have for a number of years run Askovgården, a social settlement at Nørrebro, Copenhagen.

The establishment of these new untraditional high schools will make the student material even more differentiated and the folk high schools will really live up to their name. They become schools for the whole people, irrespective of age and marital status. It is also expected that the increase in students from abroad will continue.

In 1968 two-year courses were organized all over the country in 
order to obtain the new kind of examination Højere forberedelseseksamen. This has an indirect influence on the recruitment to the high schools. There are now folk high schools which have included preparatory courses for this examination. It becomes a natural part of the picture of the folk high school since there is no examination pressure. The courses deal with languages, physics and chemistry, all of which were already on the curriculum.

But at the same time the recent years' reshuffle of the student population has meant a much greater interest in creative subjects such as music, drama, art and so on. These are subjects which many young people who intend to become kindergarten teachers or welfare officers or recreation centre teachers count on as being useful later on. And also, the still more industrialized society makes many young people crave for creative work.

Today it is the case that young people of the traditional folk high school age are taking some training or other. Many are in the middle of changing jobs. If high school courses have no relation to further education plans they would lose some of their best students.

It is far too early to judge any of the experiments I have mentioned, but I shall not deny that my own spontaneous reaction is a predilection for the family high school with kindergartens and high schools which try to bridge the generation gaps. Then, of course, there will no doubt be old folk high school students who will comment on these schools and say: Well, they are not real folk high school. It is not the three-month course or the five-month course which they knew in their youth.

But why limit the idea of a folk high school? Why stick to traditions which are out of date? It does not matter if life in and out of the classrooms has changed.

The important thing is that people with widely differing requirements and experiences meet. It is important that common experiences and spontaneous sympathy even between opponents may open up a discussion which again opens new perspectives.

But it is the education itself which lends meaning to togetherness and discussion whether it is topical politics, sociology, ancient history, psychology, art or literary matters. This is what matters. 